\title{
KEY FACTS ON CORPORATE FOUNDATIONS
}

\section{Outlook for Corporate Foundation Giving}

Giving by the nation's nearly 2,500 grantmaking corporate foundations remained basically unchanged in 2008 at an estimated $\$ 4.4$ billion. Grant dollars rose 0.8 percent from 2007, ${ }^{1}$ although this translated into a 3 percent decline after adjusting for inflation. Arguably, corporate foundations were even more directly impacted by the rapid deterioration of the economic situation in 2008 than independent and community foundations. Approximately one-quarter of corporate foundation giving in recent years has been provided by foundations tied to companies working in the banking and finance sector. The impact of this economic calamity has also moved well beyond this sector, with a sustained drop in personal and corporate spending prolonging the recession and affecting corporate earnings across the board.

Looking ahead, just over half (51 percent) of corporate foundations responding to the Foundation Center's annual forecasting survey expect to decrease their giving in $2009 .{ }^{2}$ Over three-quarters of these funders anticipate decreases in giving of greater than 10 percent.

1Figures exclude giving by corporate operating foundations. For more details see "The Impact of Foundations Established by Pharmaceutical Corporations."

2 For more details see S. Lawrence and R. Mukai, Foundation Growth and Giving Estimates: Current Outlook, The Foundation Center, New York, 2009.

Just over half of surveyed corporate foundations expect to decrease giving in 2009

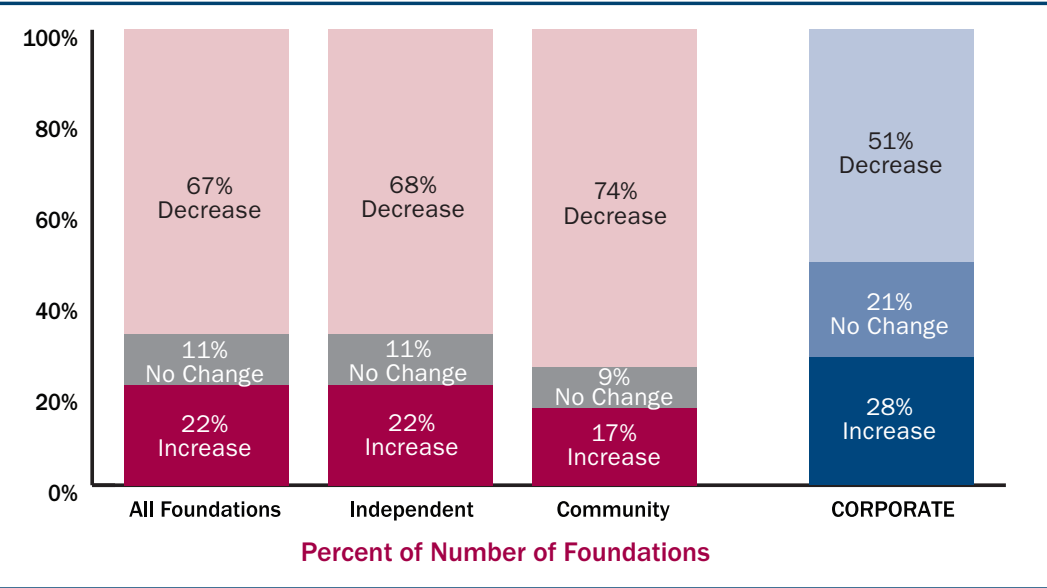

Note: A total of 1,141 foundations responded to this question. Due to rounding, figures may not add up to 100 percent.
\$4.4 billion

Estimated giving by corporate foundations

in 2008

\section{$0.8 \%$}

Estimated increase in corporate foundation giving between 2007 and 2008

\section{2,498}

Number of

grantmaking corporate foundations in 2007

\section{$21 \%$}

Share of corporate foundations reporting more than \$1 million

in giving in 2007

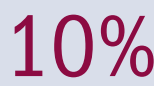

Corporate foundation giving as a share of all foundation giving in 2007 


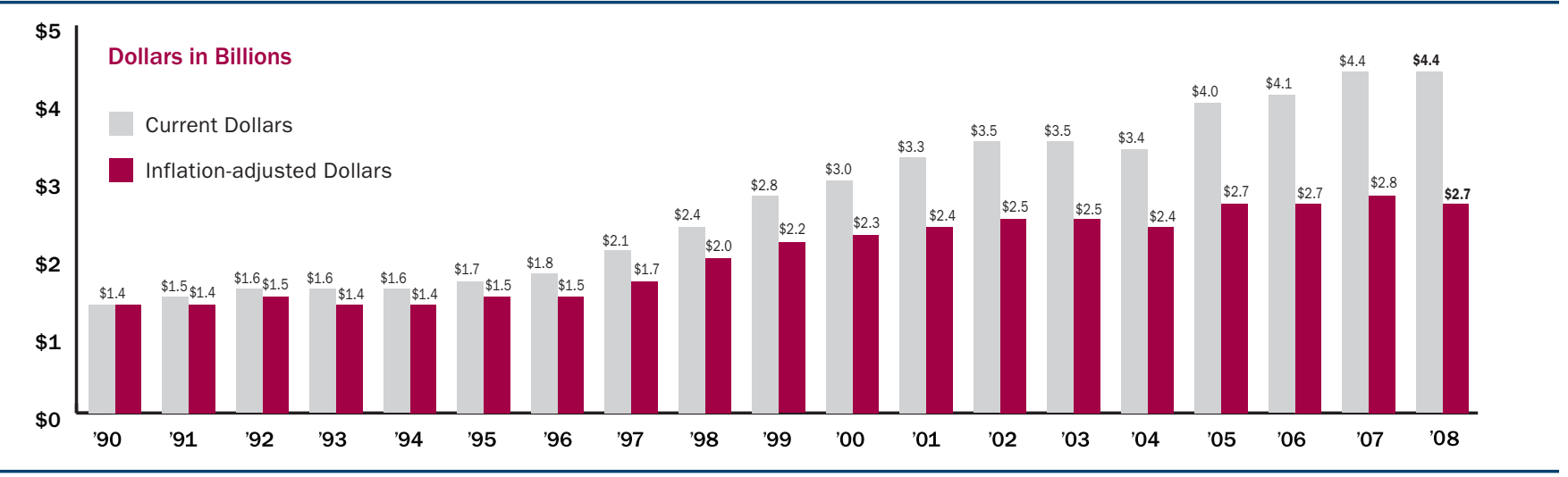

Note: Figures estimated for 2008. Excludes giving by corporate operating foundations.

After inflation, corporate foundations reported slower cumulative growth in giving than other types of foundations since 1990

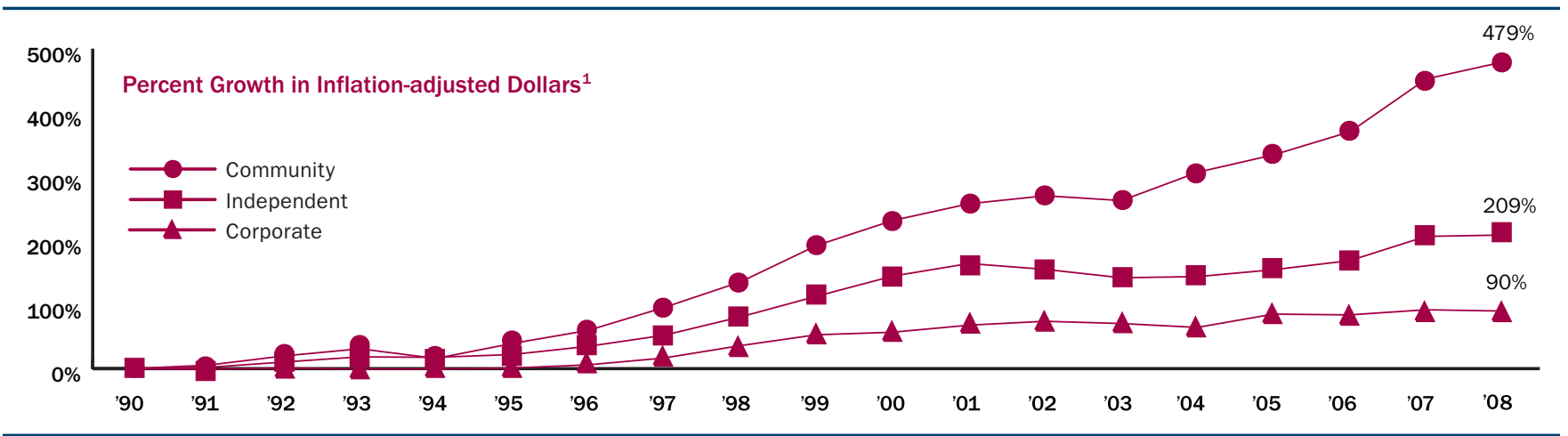

1Percent change in constant 1990 dollars based on annual average Consumer Price Index, all urban consumers (Source: U.S. Department of Labor, Bureau of Labor Statistics, as of March 2009).

Corporate foundation giving continued to decline as a share of all foundation giving in 2008

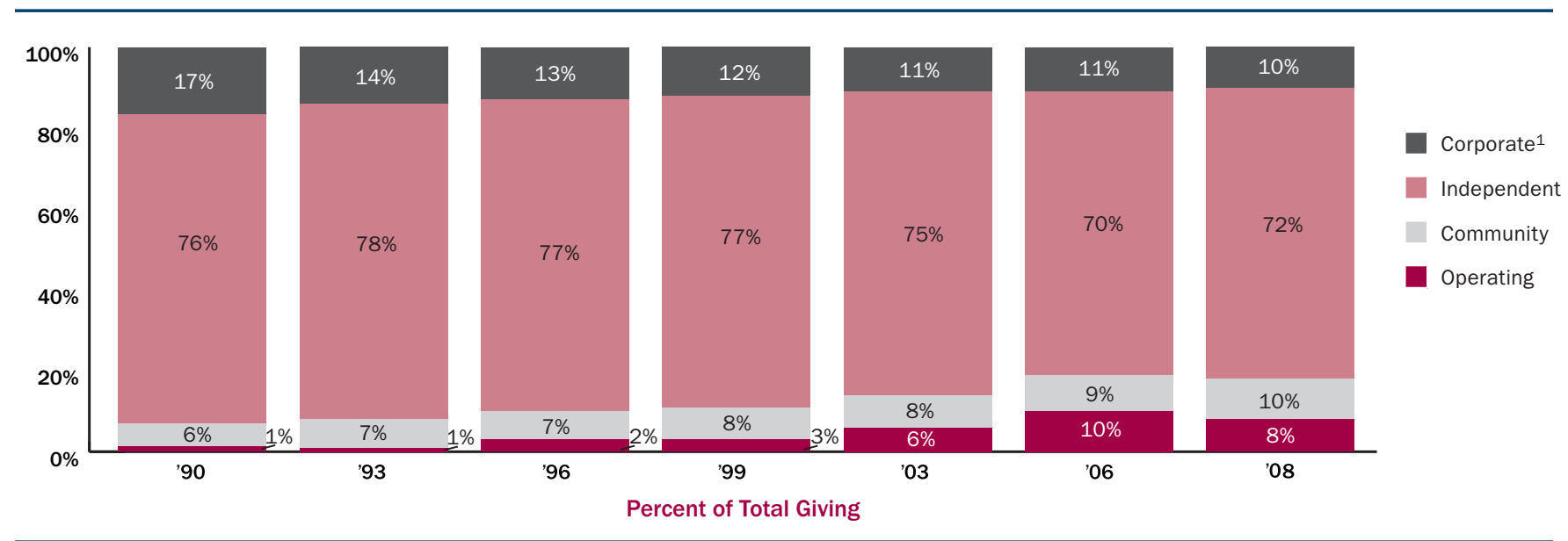

Note: Figures estimated for 2008; due to rounding, figures may not add up to 100 percent.

${ }^{1}$ Excludes giving by corporate operating foundations. 


\section{Corporate Foundation Giving Patterns, 2007}

The larger corporate foundations included in the Foundation Center's 2007 grants sample were far more likely than independent and community foundations to allocate funding for public affairs/society benefit. Much of the larger share of support for public affairs/society benefit reflected giving for philanthropy and voluntarism, including federated funds. By types of support, corporate foundations favored program support, followed by general operating support-consistent with giving patterns of community foundations.

1The Foundation Center's 2007 grants sample database includes all of the grants of $\$ 10,000$ or more awarded by 1,339 of the largest U.S. foundations, including 186 corporate foundations. The overall sample accounted for roughly half of grant dollars awarded by the more than 75,000 grantmaking U.S. foundations.
Education and public affairs/society benefit were the top priorities of corporate foundations in 2007

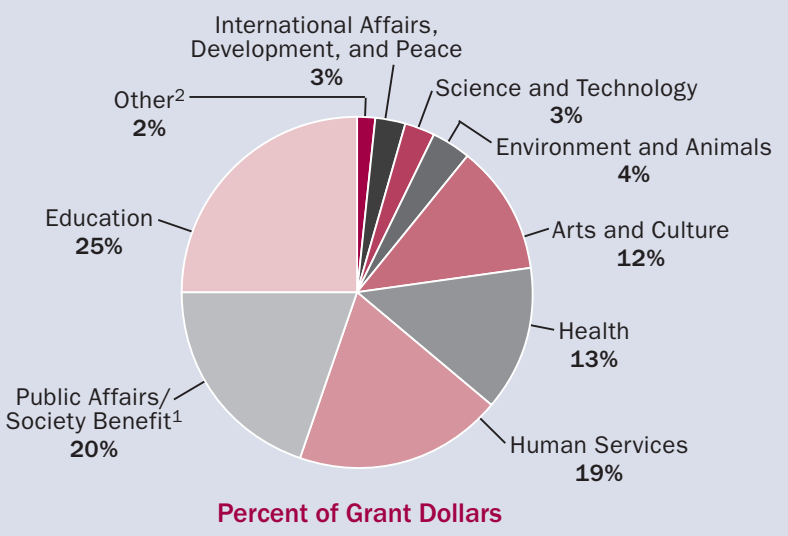

Note: Based on grants of $\$ 10,000$ or more awarded by a sample of 186 larger corporate foundations. Due to rounding, figures may not add up to 100 percent. Excludes giving by corporate operating foundations.

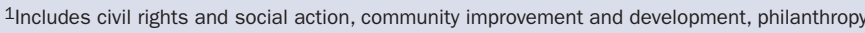
and voluntarism, and public affairs.

2Includes religion and the social sciences.

Education was the top priority of corporate foundations across most regions in 2007

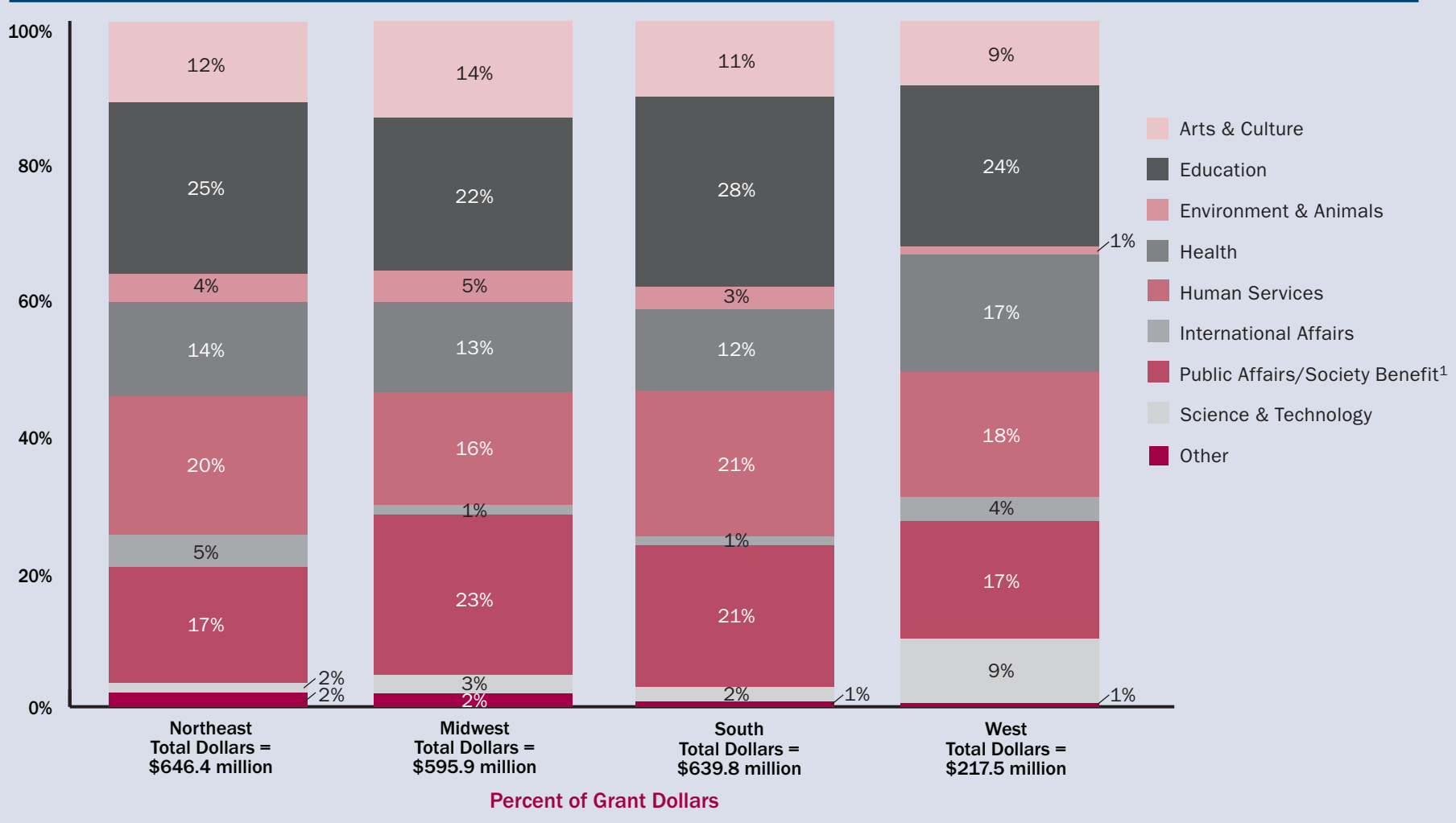

Note: Based on a sample of 186 larger corporate foundations. Due to rounding, figures may not add up to 100 percent. Excludes giving by corporate operating foundations.

${ }_{1}^{1}$ Includes civil rights and social action, community improvement and development, philanthropy and voluntarism, and public affairs. 


\section{Corporate Foundation Giving Patterns, 2007, continued}

Corporate foundations provided larger shares of funding for public affairs/society benefit than other foundations in 2007

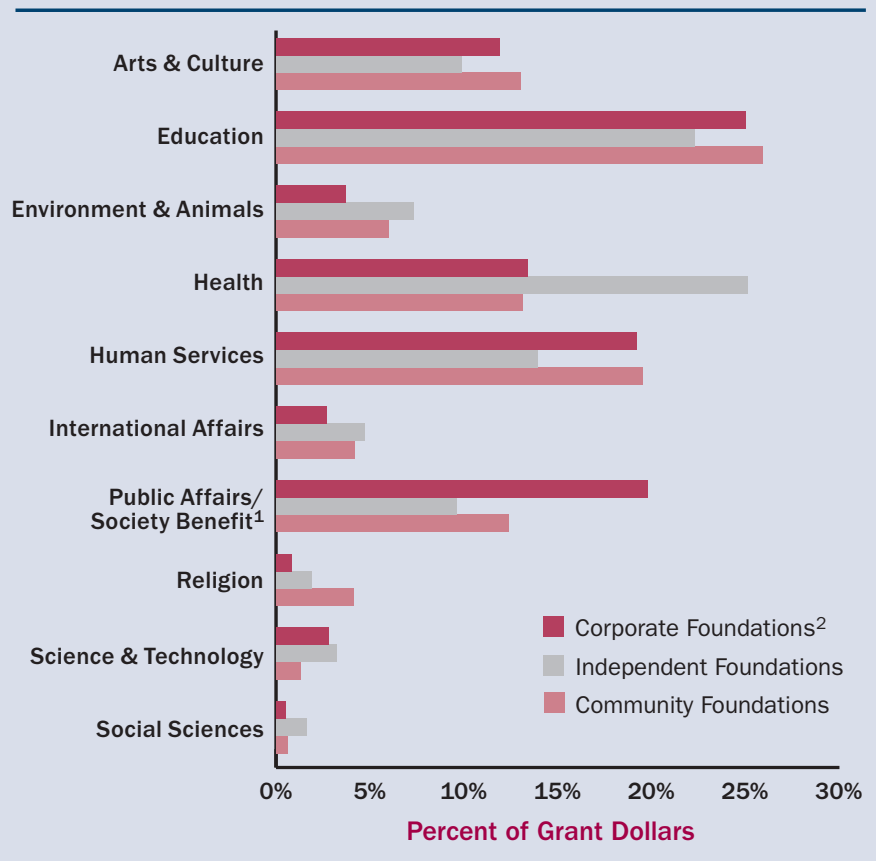

Note: Based on a sample of 1,339 larger foundations.

${ }_{1}$ Includes civil rights and social action, community improvement and development,

philanthropy and voluntarism, and public affairs.

${ }^{2}$ Excludes giving by corporate operating foundations.
Corporate foundations favored program and operating support in 2007

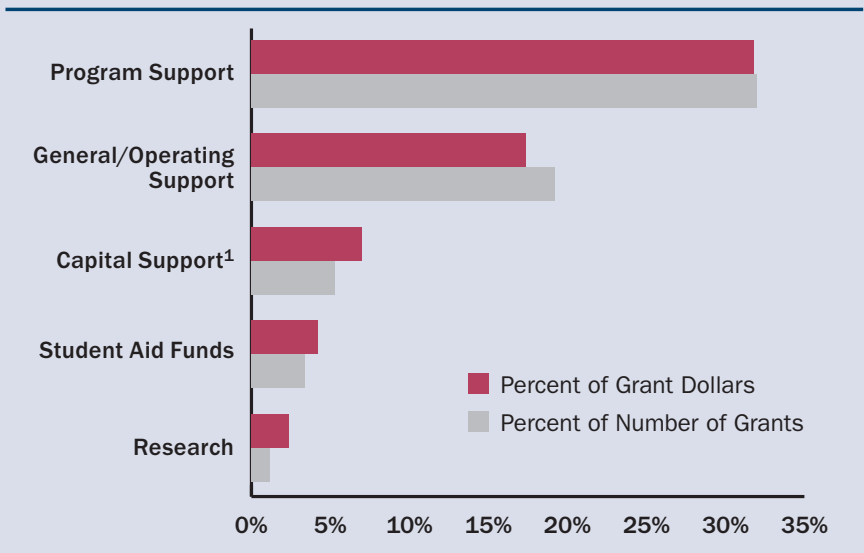

Note: Based on a sample of 186 larger corporate foundations. Nearly half of grant dollars and grants could not be identified by type of support.

${ }^{1}$ Includes endowment funds.

\section{Summary 2007 Statistics for Corporate Foundations}

\section{Change in Corporate Foundations, 2006 to 2007}

\begin{tabular}{|c|c|c|c|}
\hline & 2006 & 2007 & $\%$ Change \\
\hline No. of Foundations & 2,548 & 2,498 & -2.0 \\
\hline Total Giving & $\$ 4,097,799$ & $\$ 4,397,201$ & 7.3 \\
\hline Total Assets & $\$ 19,730,174$ & $\$ 21,923,610$ & 11.1 \\
\hline Gifts Received & $\$ 4,374,199$ & $\$ 4,417,855$ & 1.0 \\
\hline
\end{tabular}

Note: Dollars in thousands. Excludes giving by corporate operating foundations.
Corporate foundation giving represented about one-tenth of total foundation giving in $\mathbf{2 0 0 7}$

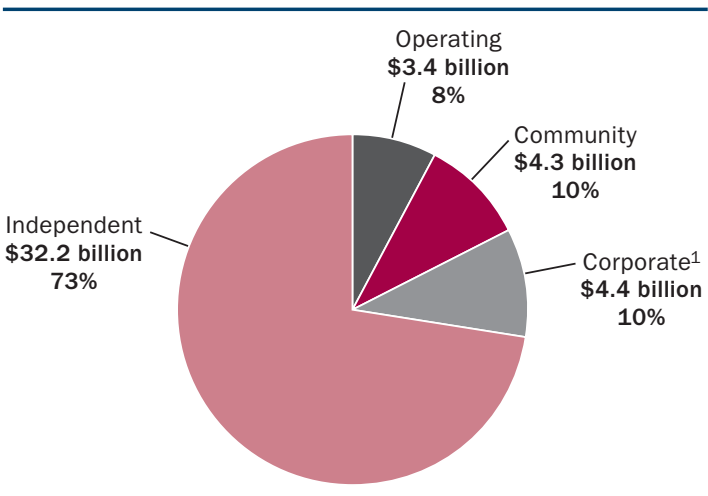

Total Giving $=\$ 44.4$ billion

Note: Based on total giving by 75,187 grantmaking private and community foundations. Due to rounding, figures may not add up to 100 percent.

${ }^{1}$ Excludes giving by corporate operating foundations. 


\section{Summary 2007 Statistics for Corporate Foundations, continued}

Top 25 Corporate Foundations by Total Giving, 2007*

\begin{tabular}{|c|c|c|c|c|c|}
\hline Foundation & State & $\begin{array}{l}\text { Total } \\
\text { Giving }\end{array}$ & $\begin{array}{c}\text { Qualifying } \\
\text { Distributions }^{2}\end{array}$ & Assets & Fiscal Date \\
\hline 1. Bank of America Charitable Foundation & NC & $\$ 188,236,685$ & $\$ 188,236,685$ & $\$ 62,928,307$ & $12 / 31 / 2007$ \\
\hline 2. Sanofi-Aventis Patient Assistance Foundation & NJ & $177,414,396$ & $177,414,396$ & 0 & $12 / 31 / 2007$ \\
\hline 3. Wal-Mart Foundation & AR & $110,895,707$ & $111,405,071$ & $4,402,583$ & $1 / 31 / 2008$ \\
\hline 4. Wachovia Foundation & NC & $96,909,222$ & $99,774,973$ & $329,114,112$ & $12 / 31 / 2007$ \\
\hline 5. Citi Foundation & NY & $96,422,843$ & $96,638,211$ & $58,626,225$ & $12 / 31 / 2007$ \\
\hline 6. GE Foundation & CT & $91,486,393$ & $93,528,071$ & $3,862,046$ & $12 / 31 / 2007$ \\
\hline 7. JPMorgan Chase Foundation & NY & $78,932,087$ & $78,932,087$ & $185,374,851$ & $12 / 31 / 2007$ \\
\hline 8. ExxonMobil Foundation & TX & $75,214,761$ & $75,514,552$ & $46,595,360$ & $12 / 31 / 2007$ \\
\hline $\begin{array}{l}\text { 9. Johnson \& Johnson Family of Companies } \\
\text { Contribution Fund }\end{array}$ & NJ & $58,734,462$ & $58,736,841$ & $28,877,956$ & $12 / 31 / 2007$ \\
\hline 10. AT\&T Foundation & TX & $57,772,461$ & $57,773,459$ & $190,920,478$ & $12 / 31 / 2007$ \\
\hline 11. BP Foundation & IL & $57,384,701$ & $58,124,908$ & $208,870,008$ & $12 / 31 / 2007$ \\
\hline 12. Verizon Company Foundation & NJ & $51,027,185$ & $55,441,699$ & $400,193,809$ & $12 / 31 / 2007$ \\
\hline 13. Pfizer Foundation & NY & $45,837,661$ & $48,186,184$ & $349,895,588$ & $12 / 31 / 2007$ \\
\hline 14. Merck Company Foundation & NJ & $44,085,873$ & $44,366,106$ & $77,962,483$ & $12 / 31 / 2007$ \\
\hline 15. UPS Foundation & GA & $42,253,878$ & $42,301,635$ & $26,402,647$ & $12 / 31 / 2007$ \\
\hline 16. Dow Chemical Company Foundation & $\mathrm{MI}$ & $40,889,095$ & $40,889,095$ & $65,109,960$ & $12 / 31 / 2007$ \\
\hline 17. Intel Foundation & OR & $39,434,599$ & $36,480,925$ & $73,815,648$ & $12 / 31 / 2007$ \\
\hline 18. Coca-Cola Foundation & GA & $36,029,520$ & $36,029,520$ & $112,677,509$ & $12 / 31 / 2007$ \\
\hline 19. Caterpillar Foundation & IL & $35,867,750$ & $35,980,330$ & $49,544,694$ & $12 / 31 / 2007$ \\
\hline 20. MetLife Foundation & NY & $35,494,772$ & $38,608,064$ & $147,665,072$ & $12 / 31 / 2007$ \\
\hline 21. Blue Shield of California Foundation & $\mathrm{CA}$ & $31,461,056$ & $34,385,612$ & $72,889,326$ & $12 / 31 / 2007$ \\
\hline 22. General Motors Foundation & $\mathrm{MI}$ & $31,433,971$ & $31,548,619$ & $203,758,120$ & $12 / 31 / 2007$ \\
\hline 23. Eli Lilly and Company Foundation & IN & $28,902,259$ & $28,902,259$ & $80,865,707$ & $12 / 31 / 2007$ \\
\hline 24. Abbott Fund & IL & $26,821,486$ & $29,939,996$ & $185,064,287$ & $12 / 31 / 2007$ \\
\hline 25. Fidelity Foundation & MA & $25,114,966$ & $27,327,650$ & $414,554,258$ & $12 / 31 / 2007$ \\
\hline
\end{tabular}

*Wells Fargo Foundation and NCC Charitable Foundation were omitted because updated fiscal information was not available. List excludes corporate operating foundations.

${ }^{1}$ Includes grants, scholarships, and employee matching gifts; excludes set-asides, loans, PRIs, and program expenses.

${ }^{2}$ Qualifying distributions are the expenditures used in calculating the required 5 percent payout; includes total giving, as well as reasonable administrative

expenses, set-asides, PRIs, operating program expenses, and amount paid to acquire assets used directly for charitable purposes.

\section{The Impact of Foundations Established by Pharmaceutical Corporations}

The vast majority of corporate foundations are established as private non-operating foundations, with a principal focus on making grants to organizations for charitable purposes. Corporations may also choose to set up private operating foundations, although this is far less common. Generally, operating foundations are established to conduct research or provide a direct service. However, in the case of many of the largest corporate operating foundations, most of their charitable support takes the form of giving medicine to individuals in need. Between 1996 and 2003, twelve pharmaceutical manufacturers established operating foundations to distribute medicine to patients with financial hardships (primarily within the United States). ${ }^{1}$ In addition, one pharmaceutical manufacturer established a non-operating corporate foundation for this purpose in the early 1990s. Together, these thirteen "pharmaceutical foundations" provided $\$ 2.6$ billion in in-kind support in 2007.
In-kind giving of medicines by some of these new pharmaceutical foundations may simply represent a shift from in-kind giving through corporate direct giving programs, which the Foundation Center does not track. Observers of the field may be surprised to learn that contributions of product are counted as part of foundations' total giving. In fact, other types of private foundations occasionally make gifts of works of art, land, or other non-cash items, which are assigned a monetary value and counted toward total giving. However, nothing in the prior history of the nation's foundation community approaches the scale of product giving by this handful of recently established foundations.

${ }^{1}$ In addition to providing pharmaceuticals to patients in need, one of these foundations, the Boehringer Ingelheim Cares Foundation, also provides monetary support to organizations involved with arts and culture, education, health, disaster relief, and human services. 


\section{Corporations' Share of All Private Giving}

Individuals account for the vast majority of private giving, followed by independent and community foundations, and corporations and corporate foundations. Nonetheless, corporations and corporate foundations provide an essential share of support. Giving USA estimated overall corporate contributions in 2007, including both foundation and direct corporate giving, at $\$ 15.7$ billion. According to the Foundation Center, corporate foundation giving of $\$ 4.4$ billion represented 28 percent of all corporate contributions, down from 32 percent in 2006. However, if corporate foundation giving was combined with the $\$ 2.6$ billion in in-kind medication giving by operating foundations established by pharmaceutical manufacturers, the 2007 share would rise to 45 percent. (For more details on these grantmakers, see "The Impact of Foundations Established by Pharmaceutical Corporations.")
Generally, corporate foundation giving represents cash contributions, while a notable portion of corporate direct giving and giving through operating foundations may reflect in-kind gifts of product. Therefore, if only cash giving was being tracked, corporate foundations would account for a larger share of overall corporate support.

Corporate giving as a share of companies' pre-tax profitsexcluding giving by corporate operating foundationsreached a record 2 percent in 1986. Following that peak, corporate giving fluctuated between 1 and 1.6 percent of pre-tax profits until 2004, when the share had dropped to below 1 percent. It fell below 1 percent again in 2006 and 2007.

\section{Summary 2007 Statistics for Corporate Foundations, continued}

\section{Companies in banking and finance accounted for the largest share of corporate foundation giving in 2007}

\begin{tabular}{|c|c|c|c|c|c|}
\hline Industrial Classification & $\begin{array}{l}\text { Number of } \\
\text { Foundations }\end{array}$ & $\%$ & $\begin{array}{l}\text { Total } \\
\text { Giving }{ }^{1}\end{array}$ & $\%$ & $\begin{array}{c}\text { Average } \\
\text { Giving per } \\
\text { Foundation }\end{array}$ \\
\hline Chemicals & 51 & 2.0 & $\$ 141,364$ & 3.2 & $\$ 2,772$ \\
\hline Computers/Office Equipment & 15 & 0.6 & 34,940 & 0.8 & 2,329 \\
\hline Food and Agriculture & 75 & 3.0 & 156,362 & 3.6 & 2,085 \\
\hline $\begin{array}{l}\text { Industrial and Commercial } \\
\text { Machinery (Not Computer) }\end{array}$ & 163 & 6.5 & 332,890 & 7.6 & 2,042 \\
\hline Paper and Like Products & 35 & 1.4 & 30,373 & 0.7 & 876 \\
\hline Petroleum/Gas/Mining & 50 & 2.0 & 192,358 & 4.4 & 3,847 \\
\hline Pharmaceuticals & 32 & 1.3 & 399,216 & 9.1 & 12,476 \\
\hline Primary Metals & 37 & 1.5 & 35,652 & 0.8 & 964 \\
\hline Printing/Publishing/Media & 77 & 3.1 & 69,191 & 1.6 & 899 \\
\hline Textiles and Apparel & 71 & 2.8 & 40,934 & 0.9 & 577 \\
\hline Transportation Equipment & 71 & 2.8 & 149,025 & 3.4 & 2,099 \\
\hline Other Manufacturing & 266 & 10.7 & 268,611 & 6.1 & 1,010 \\
\hline Total Manufacturing & 943 & 38.1 & $\$ 1,851,217$ & 42.2 & $\$ 1,963$ \\
\hline Banking and Finance & 443 & 17.7 & $\$ 1,103,368$ & 25.2 & $\$ 2,311$ \\
\hline Insurance & 140 & 5.6 & 433,689 & 9.9 & 3,098 \\
\hline Retail and Wholesale Trade & 330 & 13.2 & 368,618 & 8.4 & 1,117 \\
\hline Telecommunications & 42 & 1.7 & 155,829 & 3.5 & 3,710 \\
\hline Transportation & 28 & 1.1 & 72,522 & 1.7 & 2,590 \\
\hline Utilities & 94 & 3.8 & 155,967 & 3.5 & 1,659 \\
\hline Other Services & 454 & 18.2 & 248,049 & 5.6 & 546 \\
\hline Total Nonmanufacturing & 1,531 & 61.9 & $\$ 2,538,042$ & 57.8 & $\$ 1,658$ \\
\hline Unspecified & 24 & 1.0 & 7,942 & 0.2 & $\$ 331$ \\
\hline Total & 2,498 & 100.0 & $\$ 4,397,201$ & 100.0 & $\$ 1,760$ \\
\hline
\end{tabular}

Note: Dollars in thousands. Categories are based on the Conference Board's classification of corporations using Standard Industrial Classification codes.

1 Includes grants, scholarships, and employees matching gifts; excludes set-asides, loans, PRIs, and program expenses.

\section{Corporate giving accounted for 5 percent of private philanthropic giving in $\mathbf{2 0 0 7}$}

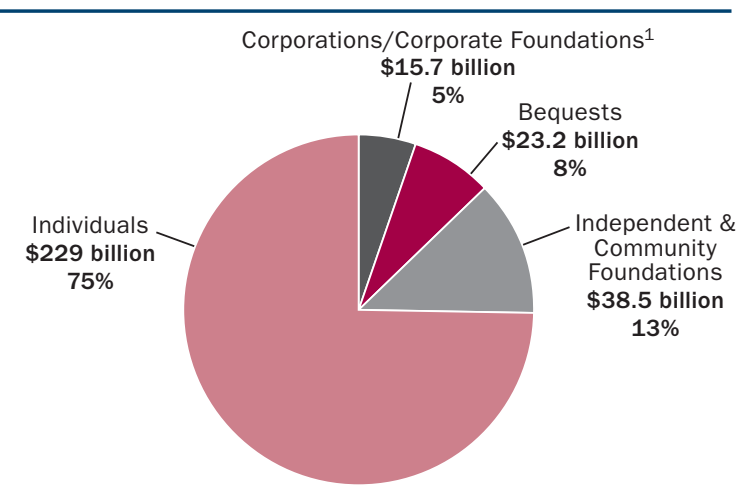

Total Private Philanthropic Giving $=\$ 306.4$ billion

Note: Based on data from Giving USA Foundation, Giving USA 2008, ed. by M. Brown, Illinois; Giving USA Foundation, 2008. Due to rounding, figures may not add up to 100 percent.

1 Of total corporate giving for 2007 , $\$ 4.4$ billion (28\%) was paid through corporate foundations. 
Corporate Foundations by State, 2007

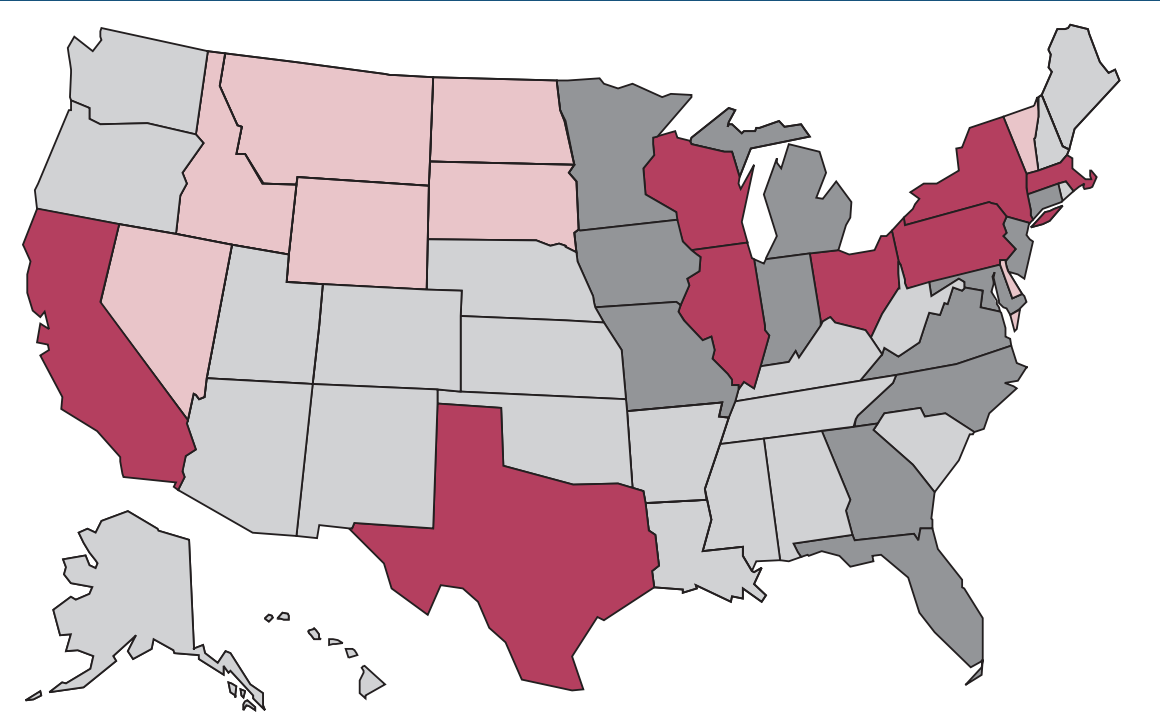

Total Corporate Foundations $=2,498$

$100+\quad 40-$ under $100 \quad 10-$ under $40 \quad$ Under 10

The Northeast accounted for the largest share of corporate foundation giving in 2007

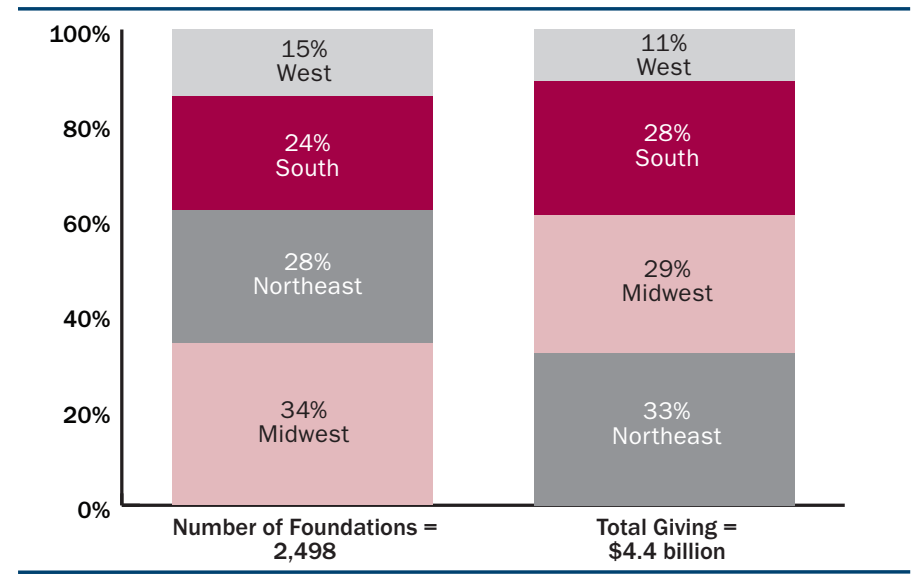

Note: Giving includes grants, scholarships, and employee matching gifts; excludes set-asides, loans, PRIs, and program expenses. Due to rounding, figures may not add up to 100 percent. Excludes giving by corporate operating foundations.
One-fifth of corporate foundations reported more than $\$ 1$ million in giving in 2007

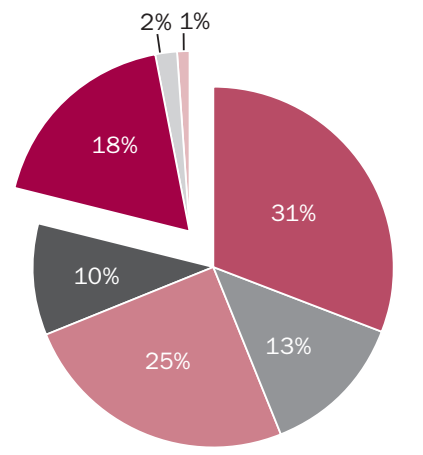

Total Giving Range

$\$ 25$ million+

$\$ 10$ million-\$25 million

\$1 million $-\$ 10$ million

$\$ 500,000-\$ 1$ million

$\$ 100,000-\$ 500,000$

$\$ 50,000-\$ 100,000$

Under $\$ 50,000$

Percent of Number of Foundations

Note: Based on total giving by 2,498 grantmaking corporate foundations. Excludes giving by corporate operating foundations.

Over 20 percent of corporate foundations have been established in the 2000s

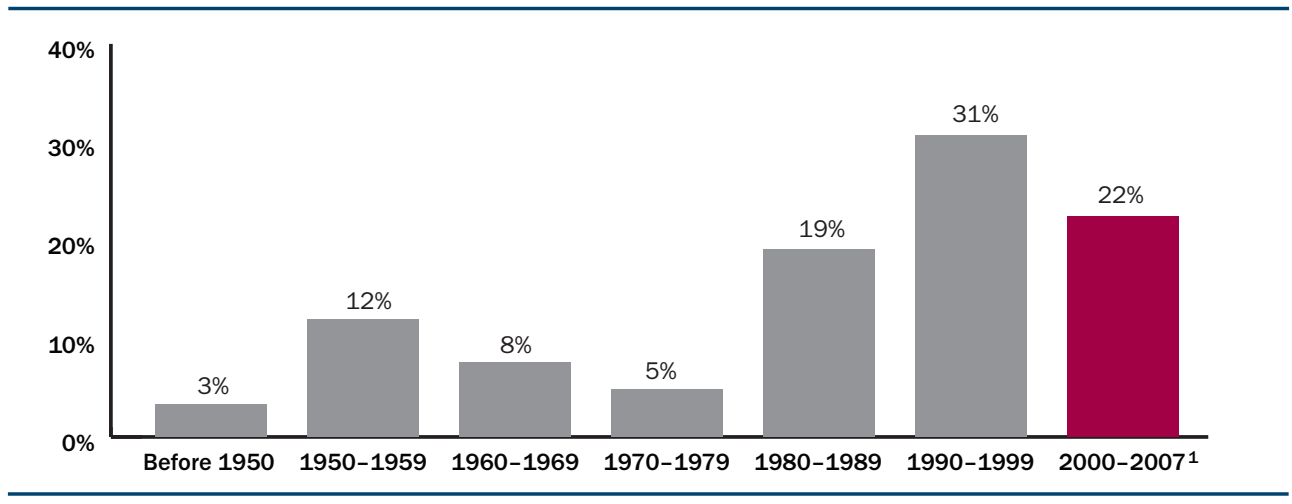

Note: Excludes 253 grantmaking corporate foundations that lack establishment information.

1Data incomplete for the period 2000-2007. 
